DOI: $10.15593 / 2224-9354 / 2020.1 .14$

УДК 330.341.1:621

Е.С. Лобова, Л. Н. Мамаева,

Т.Г. Ментемирова, К.А. Шишкина

\author{
ПЕРСПЕКТИВЫ СТРАТЕГИЧЕСКОГО РАЗВИТИЯ \\ ПРЕДПРИЯТИЙ МАШИНОСТРОИТЕЛЬНОГО КОМПЛЕКСА \\ В РАМКАХ ПРИОРИТЕТНЫХ НАПРАВЛЕНИЙ РАЗВИТИЯ СТРАНЫ
}

\begin{abstract}
На современное состояние рынков промышленной продукции особое влияние оказывают процессы, связанные с повсеместной цифровизацией и развитием концепции «Индустрия 4.0». Институционализация приоритетных направлений и стратегий отраслевого развития на уровне региональной власти должна служить основой для формирования инновационных принципов взаимодействия и развития новых подходов к определению конкурентоспособности. Составляющими элементами вектора стратегического развития Пермского края, ориентированного на формирование драйверов роста, являются как эволюционно сложившиеся структурные особенности промышленности, так и инновационные решения в плане поиска точек роста высокотехнологичных рынков. Цель исследования - выявить основные параметры стратегического позиционирования предприятий машиностроительного комплекса, отвечающие условиям стратегирования инновационно ориентированных участников всех уровней социально-экономической системы. Для достижения цели были выявлены основные перспективные направления развития промышленности Пермского края и их соотношение с концепцией «Индустрия 4.0». Обоснованы принципы формирования параметрических показателей реализуемости «драйверов роста» применительно к машиностроительному комплексу. Определены взаимосвязи критериев стратегического управления на ведущих предприятиях машиностроительного комплекса с требующими достижения показателями отраслевых стратегий макро- и мезоуровней. Подчеркнута роль институционализации стратегических параметров при фрормировании технологического потенциала предприятий машиностроительного комплекса. К основным результатам можно отнести механизм обоснования параметров технико-экономического планирования деятельности предприятий-лидеров Пермского края, а также параметры, на основе которых можно судить о достижении интересов участников стратегического планирования точек роста.

Ключевые слова: промышленность, предприятия машиностроительного комплекса, стратегическое планирование, Индустрия 4.0.
\end{abstract}

(С) Лобова Е.С., Мамаева Л.Н., Ментемирова Т.Г., Шишкина К.А., 2020

Лобова Елена Сергеевна - канд. экон. наук, доцент кафедры экономики и управления промышленным производством, ФГБОУ ВО «Пермский национальный исследовательский политехнический университет», e-mail: bykova555@rambler.ru.

Мамаева Людмила Николаевна - канд. экон. наук, доцент кафедры экономической безопасности ФГБОУ ВО «Саратовский социально-экономический институт (филиал) Российского экономического университета им. Г.В. Плеханова», e-mail: L.Mamaeva2014@yandex.ru.

Ментемирова Татьяна Григорьевна - магистрант кафедры экономики и управления промышленным производством ФГБОУ ВО «Пермский национальный исследовательский политехнический университет», e-mail: tatyanamentemirova@yandex.ru.

Шишкина Ксения Андреевна - магистрант кафедры экономики и управления промышленным производством ФГБОУ ВО «Пермский национальный исследовательский политехнический университет», e-mail: shishckina.xenia2014@yandex.ru. 
Направление технологического развития отраслей страны определяется лидерами в создании, разработках и внедрении высоких технологий - отраслями и подотраслями машиностроительного комплекса. Предприятиям машиностроения отводится ведущая роль в производстве техники, оборудования и реализации инновационных производственных процессов в других отраслях экономики, позволяющих решить проблемы перехода на новый технологический уклад с реализацией концепции цифровой экономики [1].

Вопросы, связанные с оценкой перспектив развития предприятий машиностроительного комплекса, вызывают особый интерес не случайно. Вопервых, подходят к концу действия координирующие документы, определившие основные стратегические направления развития до 2020 г., а разработанные отраслевые стратегии периода до 2030 г. охватывают не все отрасли машиностроения; во-вторых, подведение итогов по их реализации не может быть проведено без поправки на влияние вектора ускорения индустриализации экономики страны и формирование «драйверов роста» и инновационных структур в экономике региона, которые должны послужить отправной точкой при планировании нового этапа стратегического развития; в-третьих, все определеннее понимание роли машиностроения как «локомотива» в процессах модернизации и повышения технико-технологического уровня производственных и непроизводственных секторов экономики. Описанные моменты не могут быть решены отдельно друг от друга и безотносительно принципов встраивания в систему технико-экономической парадигмы геополитического развития. Это значит, что процессы стратегического планирования деятельности предприятий машиностроения должны базироваться не только на принятых «моделях наилучшей деловой практики, состоящей из всеобъемлющих общих технологических и организационных принципов» [2, с. 40], отражающих воплощение желаемого уровня технологического уклада страны, но иметь возможность гибко адаптироваться к формируемым инновативным ценностям и в опережающем режиме создавать потенциал «структурной инклюзии» [3, с. 183]. Эмпирические исследования факторов формирования экономического роста красноречиво подтверждают тенденции в смещении структурно определяющих параметров в сторону интеллектуальных ресурсов [4].

Для того чтобы выявить индикаторы стратегического планирования на машиностроительных предприятиях, позволяющие оценить потенциал способности развиваться в соответствии с вектором приоритетных направлений государственного и регионального стратегирования необходимо решить следующие задачи:

1. Провести кросс-анализ стратегий предприятий подотраслей машиностроения г. Перми и Пермского края в соответствии со стратегиями развития страны. 
2. Определить параметры, позволяющие сформировать «драйверы роста» технико-экономического развития региона.

3. На основе сопоставительного анализа параметров стратегического планирования макро- и мезоуровней социально-экономической системы определить набор индикаторов стратегического планирования машиностроительного предприятия.

В выборку анализируемых предприятий вошли машиностроительные предприятия - партнеры научно-образовательной деятельности ФГБОУ ВО «Пермский национальный исследовательский политехнический университет». Несмотря на то, что исследования сопоставимости отраслевых стратегий, сформированных для отраслей машиностроения, уже проводились [5], в соответствии с поставленными задачами требуется конкретизация параметров с учетом особенностей для предприятий Пермского края. Результаты проведенного кросс-анализа предприятий с высоким уровнем потенциала в региональной экономике представлены в табл. 1.

Таблица 1

Результаты кросс-анализа стратегической деятельности машиностроительных предприятий - партнеров ПНИПУ

\begin{tabular}{|c|c|c|}
\hline Стратегия & $\begin{array}{l}\text { Варианты стратегий и их содержание, } \\
\text { в большей степени соответствующие } \\
\text { направлениям развития предприятий }\end{array}$ & $\begin{array}{c}\text { Примеры реализации } \\
\text { стратегий в деятельности } \\
\text { предприятий } \\
\end{array}$ \\
\hline \begin{tabular}{|l|} 
Стратегия \\
развития \\
транспортно- \\
го машино- \\
строения РФ \\
на период до \\
2030 г.
\end{tabular} & $\begin{array}{l}\text { Умеренно-оптимистичный вариант. } \\
\text { Применение целевых мер государствен- } \\
\text { ной поддержки отрасли в дополнение к } \\
\text { общим механизмам поддержки промыш- } \\
\text { ленных производителей, закрепленных в } \\
\text { законодательстве Российской Федерации } \\
\text { и стимулирующих выход продукции рос- } \\
\text { сийского машиностроения на мировой } \\
\text { рынок }\end{array}$ & $\begin{array}{l}\text { ОАО «Александровский ма- } \\
\text { шиностроительный завод» [6], } \\
\text { АО Пермский завод «Маши- } \\
\text { ностроитель» [7], } \\
\text { АО Пермский вагоноремонт- } \\
\text { ный завод «Ремпутьмаш», } \\
\text { ОАО Пермский вагоно- } \\
\text { строительный завод. } \\
\text { Компания «Авиационные } \\
\text { редуктора и трансмиссии } \\
(\text { Редуктор ПМ)» [8] }\end{array}$ \\
\hline \begin{tabular}{|l} 
Стратегия \\
развития \\
энергомаши- \\
ностроения \\
РФ на 2010-- \\
2020 гг. и на \\
перспективу \\
до 2030 г.
\end{tabular} & $\begin{array}{l}\text { 1. Эволющионный вариант. Осуществ- } \\
\text { ляется прямо инвестирование финансо- } \\
\text { вых ресурсов при сохранении сущес- } \\
\text { вующих механизмов формирования и } \\
\text { внедрения новейших технологий. } \\
\text { 2. Инвестиционный вариант. Осущест- } \\
\text { вляется формирование в компаниях, } \\
\text { разрабатывающих и производящих обо- } \\
\text { рудование, четко определенных центров } \\
\text { компетенции и развитие из научн-- } \\
\text { технологической базы за счет инвести- } \\
\text { ций. }\end{array}$ & $\begin{array}{l}\text { АО «ОДК-СТАР» [9], } \\
\text { ПАО «НПО „Искра“» [10], } \\
\text { ООО «Джон Крейн - Искра» } \\
{[11],} \\
\text { АО «ОДК - Пермские мото- } \\
\text { ры» [12], } \\
\text { ПАО «Синергия» [13], } \\
\text { Транснациональный холдинг } \\
\text { АО «НОВОМЕТ-Пермь» [14], } \\
\text { ООО «Очерский машино- } \\
\text { строительный завод» [15], }\end{array}$ \\
\hline
\end{tabular}


Окончание табл. 1

\begin{tabular}{|c|c|c|}
\hline Стратегия & $\begin{array}{l}\text { Варианты стратегий и их содержание, } \\
\text { в большей степени соответствующие } \\
\text { направлениям развития предприятий }\end{array}$ & $\begin{array}{c}\text { Примеры реализации } \\
\text { стратегий в деятельно- } \\
\text { сти предприятий }\end{array}$ \\
\hline & $\begin{array}{l}\text { 3. Партнерский вариант. Осуществляется раз- } \\
\text { витие механизмов государственно-частного } \\
\text { партнерства в части разработки и передачи } \\
\text { инновационных технологий энергомашино- } \\
\text { строения в энергетику, привлечение частного } \\
\text { бизнеса к участию в реализации инвестицион- } \\
\text { ных проектов в сочетании с усилением их роли } \\
\text { в выработке и принятии решений }\end{array}$ & $\begin{array}{l}\text { 3АО «Пермская компа- } \\
\text { ния нефтяного машино- } \\
\text { строения» [16] }\end{array}$ \\
\hline \begin{tabular}{|l|} 
Стратегия \\
развития тя- \\
желого маши- \\
ностроения \\
на период до \\
2020 г.
\end{tabular} & $\begin{array}{l}\text { Инновачионный вариант. } \\
\text { Подразумевает непрерывную поддержку } \\
\text { производителей и спроса на российском } \\
\text { рынке со стороны государства, проведение } \\
\text { мероприятий по поддержке НИОКР, модер- } \\
\text { низации производственных мощностей, сти- } \\
\text { мулированию иностранных производителей } \\
\text { к передаче технологий, осуществление мер } \\
\text { по повышению инвестиционной привлека- } \\
\text { тельности отрасли }\end{array}$ & $\begin{array}{l}\text { ООО «Краснокамский } \\
\text { завод тяжелого маши- } \\
\text { ностроения» [17], } \\
\text { АО «ОДК-Пермские } \\
\text { моторы» [12], } \\
\text { ПАО «Мотовилихин- } \\
\text { ские заводы» [18] }\end{array}$ \\
\hline $\begin{array}{l}\text { Государст- } \\
\text { венная про- } \\
\text { грамма РФ } \\
\text { «Развитие } \\
\text { авиационной } \\
\text { промышлен- } \\
\text { ности» на } \\
\text { 2013-2025 гг. }\end{array}$ & $\begin{array}{l}\text { Развитие частно-государственного nарт- } \\
\text { нерства и международной интеграции. } \\
\text { Ответственность за определение продуктового } \\
\text { ряда, за успех коммерческих проектов на внут- } \\
\text { реннем и мировом рынках, за привлечение в } \\
\text { отрасль внебюджетных инвестиций, в том чис- } \\
\text { ле на основе разделения рисков с зарубежными } \\
\text { партнерами, возлагается на бизнес }\end{array}$ & $\begin{array}{l}\text { АО «ОДК-Авиадвига- } \\
\text { тель» [19], } \\
\text { АО «ОДК-Пермские } \\
\text { моторы» [12] }\end{array}$ \\
\hline $\begin{array}{l}\text { Стратегия } \\
\text { развития су- } \\
\text { достроитель- } \\
\text { ной промыш- } \\
\text { ленности на } \\
\text { период до } \\
2020 \text { г. и на } \\
\text { дальнейшую } \\
\text { перспективу }\end{array}$ & $\begin{array}{l}\text { Инерицональный вариант. } \\
\text { Базируется на наиболее вероятной бюджет- } \\
\text { ной поддержке в рамках уже намеченных к } \\
\text { реализации федеральных целевых программ } \\
\text { и их пролонгации в перспективе }\end{array}$ & $\begin{array}{l}\text { ООО «Верхнекамский } \\
\text { судостроительный ком- } \\
\text { плекс» [20] }\end{array}$ \\
\hline
\end{tabular}

По полученным данным можно сделать выводы о том, что уровень диверсификации продуктового портфеля определяет количество и состав регламентирующих отраслевых стратегий.

В отличие от стратегий, приведенных в табл. 1, стратегическое планирование предприятий подотрасли сельскохозяйственного машиностроения базируется на Доктрине продовольственной безопасности страны. Результаты анализа основных критериев и целей приведены в табл. 2. 
Результаты кросс-анализа стратегической деятельности предприятий - партнеров ПНИПУ (по подотрасли сельскохозяйственного машиностроения)

\begin{tabular}{|c|c|c|c|}
\hline Стратегия & Критерий & $\begin{array}{c}\text { Цели } \\
\text { стратегии }\end{array}$ & $\begin{array}{c}\text { Примеры } \\
\text { предприятий }\end{array}$ \\
\hline $\begin{array}{l}\text { Стратегия разви- } \\
\text { тия сельскохо- } \\
\text { зяйственного } \\
\text { машиностроения } \\
\text { России на период } \\
\text { до } 2030 \text { г. }\end{array}$ & $\begin{array}{l}\text { Мероприятия стратегии нацелены } \\
\text { на достижение показателей Док- } \\
\text { трины продовольственной безо- } \\
\text { пасности РФ в части снижения } \\
\text { зависимости от импорта техники } \\
\text { и технологий, а также обеспече- } \\
\text { ния модернизации сельского хо- } \\
\text { зяйства страны для увеличения } \\
\text { выпуска базовой сельхозпродук- } \\
\text { ции }\end{array}$ & $\begin{array}{l}\text { Обеспечение } \\
\text { ускоренного } \\
\text { роста производ- } \\
\text { ства продукции } \\
\text { сельскохозяй- } \\
\text { ственного ма- } \\
\text { шиностроения } \\
\text { в стране }\end{array}$ & $\begin{array}{l}\text { ООО «Навига- } \\
\text { тор - Новое } \\
\text { машинострое- } \\
\text { ние» [21], } \\
\text { АО «Пермглав- } \\
\text { снаб» [22] }\end{array}$ \\
\hline
\end{tabular}

Необходимо также отметить роль концепции «Индустрия 4.0» на процессы адаптации ранее описанных стратегий развития. В частности, рассмотрим то, каким образом в производственных программах должны быть отражены требования к производству оборудования для предприятий нефтегазового сектора, высокоточного комплекса и двигателестроения. Основные критерии концепции, требующие адаптации разработанных стратегий, приведены в табл. 3.

Таблица 3

Сопоставление целей концепции «Индустрия 4.0» и деятельности предприятий-производителей высокотехнологичной продукции

\begin{tabular}{|c|c|c|}
\hline Отрасли & Цели концепции & $\begin{array}{c}\text { Примеры предприятий, деятельность } \\
\text { которых отражает цели концепции } \\
\text { «Индустрия 4.0» }\end{array}$ \\
\hline $\begin{array}{l}\text { Нефтега- } \\
\text { зовые }\end{array}$ & $\begin{array}{l}\text { Цифровая трансформация, } \\
\text { реализующийся через рабо- } \\
\text { ту с большими данными. } \\
\text { Аналитика больших данных } \\
\text { как в разведке и добыче, так } \\
\text { и в переработке и сбыте го- } \\
\text { товой продукции }\end{array}$ & $\begin{array}{l}\text { Завод «Синергия» [13]. Современное, дина- } \\
\text { мично развивающееся предприятие по про- } \\
\text { ектированию и изготовлению плунжерных } \\
\text { насосов высокого давления мощностью до } \\
2500 \text { л.с. На базе собственных насосов за- } \\
\text { вод выпускает насосные установки для бу- } \\
\text { рения, ППд, ГРП, КРС, а также производит } \\
\text { запорную арматуру высокого давления до } \\
1000 \text { атм. } \\
\text { Завод НОВОМЕТ [14]. Инновационные раз- } \\
\text { работки двигателей, предназначенных для } \\
\text { добычи нефти на высокотермальных место- } \\
\text { рождениях }\end{array}$ \\
\hline
\end{tabular}


Окончание табл. 3

\begin{tabular}{|c|c|c|}
\hline Отрасли & Цели концепции & $\begin{array}{c}\text { Примеры предприятий, деятельность } \\
\text { которых отражает цели концепции } \\
\text { «Индустрия 4.0» }\end{array}$ \\
\hline \begin{tabular}{|l|} 
Отрасли \\
высоко- \\
точного \\
комплекса \\
экономики \\
\end{tabular} & $\begin{array}{l}\text { Ускоренная интеграция ки- } \\
\text { берфизических систем в за- } \\
\text { водские процессы. Внедре- } \\
\text { ние автоматизации абсолют- } \\
\text { но всех процессов и этапов } \\
\text { производства: цифровое } \\
\text { проектирование изделия, } \\
\text { удаленная настройка обору- } \\
\text { дования на заводе под тех- } \\
\text { нические требования для } \\
\text { выпуска конкретного «умно- } \\
\text { го» продукта и др. }\end{array}$ & $\begin{array}{l}\text { Galileosky [23]. Занимается проектировани- } \\
\text { ем, выпуском и реализацией приборов для } \\
\text { систем спутникового мониторинга назем- } \\
\text { ного и водного транспорта. Оборудование } \\
\text { работает с навигационными системами } \\
\text { GPS/ГЛОНАСС. Продукция компании вы- } \\
\text { соко ценится не только на российском рын- } \\
\text { ке, но пользуется спросом в ЕС, США и } \\
\text { странах Азии. Устройства проектируются с } \\
\text { учетом новейших технологий и отличаются } \\
\text { высоким уровнем качества. } \\
\text { ПАО ПНППК [24]. Занимается разработкой } \\
\text { и производством датчиков и систем для } \\
\text { навигации, стабилизации и ориентации раз- } \\
\text { личного рода подвижных объектов. Это } \\
\text { один из ведущих российских поставщиков } \\
\text { навигационных приборов и систем. } \\
\text { ПАО «Мотовилихинские заводыл» [18]. Ве- } \\
\text { дут разработки роторно-управляемых сис- } \\
\text { тем для осуществления удаленного доступа } \\
\text { к буровым скважинам. } \\
\text { НПО «Энергомаш» [25]. Ведут разработку } \\
\text { ракетных двигателей нового поколения } \\
\text { РД-171МВ }\end{array}$ \\
\hline
\end{tabular}

Реализация отраслевых стратегий и концепций, представленных в табл. 1-3, главным образом должна обеспечить стабильность промышленного развития, повысить способность отвечать новым требованиям конкурентоспособности на внешнем и внутреннем рынках высокоточной продукции.

Что касается стратегирования вектора развития на региональном уровне, то «драйверы роста» выстраиваются, прежде всего, на основе реализации проектов цифровизации [26]. Пермский край один из первых разработал программу внедрения цифровой экономики в жизнь общества и производство. Реализация в Пермском крае промышленных проектов по освоению калийных месторождений и производству формальдегидов невозможна без инвестиций в процессы модернизации через выстроенную систему государственной поддержки предприятий, которые включают в себя инвестконтракты, различные фонды поддержки промышленности, программы субсидирования [27]. Планируемые объемы инвестиции в промышленность с 2018 по 2022 г. составят около 1,5 трлн руб. 
Реализация схем взаимодействия инновационно ориентированных субъектов промышленных рынков в «драйверах роста» в Пермском крае оказало благоприятное воздействие на валовой региональный продукт (ВРП), что демонстрирует диаграмма динамики основных параметров (рис. 1, 2), составленная на основе актуальных данных Федеральной службы государственной статистики по Пермскому краю за 2019 г. [28].

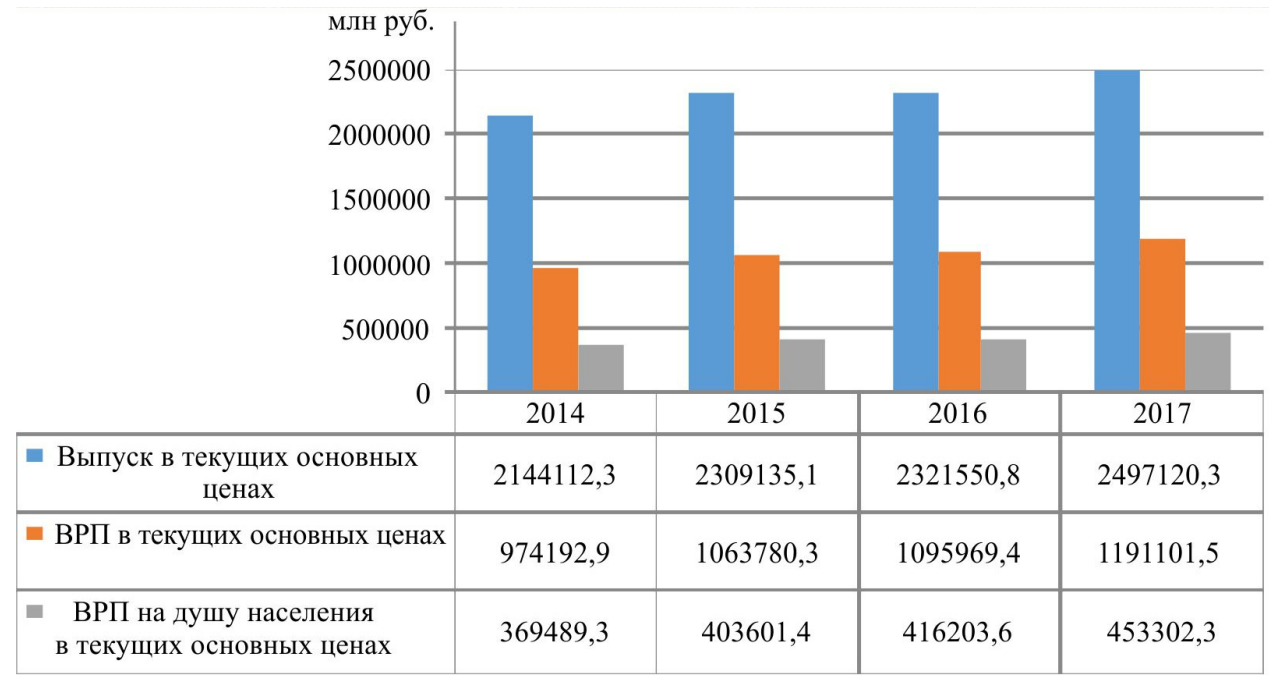

Рис. 1. Производство ВРП за 2014-2017 гг., млн руб.

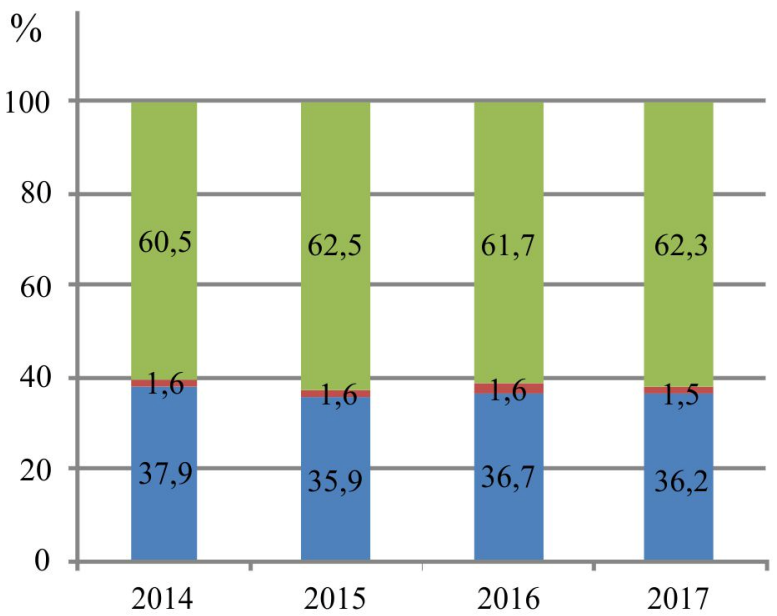

- Валовая прибыль экономики и валовые смешанные доходы

- Другие чистые налоги на производство

- Оплата труда наемных работников

Рис. 2. Источники формирования ВРП за 2014-2017 гг., \%

За анализируемый период выпуск в текущих основных ценах увеличился на $16 \%$, при этом в 2015 г. - на $8 \%$, в 2016 г. - на $1 \%$, в 2017 г. - на 8 \%. Такая тенденция обусловлена ростом промышленного производства. 
ВРП (валовая добавленная стоимость) и ВРП на душу населения в текущих основным ценах выросли на $22 \%$. Наибольшее увеличение произошло в период с 2014 по 2015 г. и составило $9 \%$.

На рис. 2 видно, что основным источником формирования ВРП за 20142017 гг. являются валовая прибыль экономики и валовые смешанные доходы. Доля данного показателя в общем объеме ВРП незначительно колебалась от минимального значения - 60,5 \% в 2014 г. до максимального - 62,5 \% в 2015 г. Второй по величине источник формирования ВРП - это оплата труда наемных работников. Доля этого показателя в общем объеме ВРП составляла в 2014-2017 гг. от 35,9 до 37,9\%. Наименьшим источником ВРП являются другие чистые налоги на производство. Величина данного показателя в период 2014-2016 гг. составляла 1,6 \% общего объема ВРП, а в 2017 г. показатель сократился до $1,5 \%$.

Рассмотрим, каким образом соотносятся отраслевые стратегии развития с нормативно-правовыми документами регионального уровня и какие результаты это взаимодействие имеет. Согласно данным министерства промышленности Пермского края [29], на сегодняшний день имеются проекты, обеспечивающие реализацию целевых установок макроуровня и регионального уровня в рамках инновационных структур (табл. 4).

Таблица 4

Сопоставление стратегий РФ, государственных программ

Пермского края и результатов проектной деятельности

\begin{tabular}{|c|c|c|}
\hline Стратегии развития & $\begin{array}{c}\text { Нормативно-правовая } \\
\text { база }\end{array}$ & $\begin{array}{c}\text { Проекты, реализуемые } \\
\text { в Пермском крае }\end{array}$ \\
\hline $\begin{array}{l}\text { Стратегия развития } \\
\text { автомобильной про- } \\
\text { мышленности России } \\
\text { на период до } 2020 \text { г. }\end{array}$ & $\begin{array}{l}\text { «Развитие промыш- } \\
\text { ленности и повыше- } \\
\text { ние ее конкуренто- } \\
\text { способности» [31] }\end{array}$ & $\begin{array}{l}\text { Проект «Пермский инженерно- } \\
\text { промышленный форум» }\end{array}$ \\
\hline $\begin{array}{l}\text { Стратегия развития } \\
\text { транспортного маши- } \\
\text { ностроения РФ на пе- } \\
\text { риод до } 2030 \text { г. }\end{array}$ & $\begin{array}{l}\text { «Развитие промыш- } \\
\text { ленности и повыше- } \\
\text { ние ее конкуренто- } \\
\text { способности» [31] }\end{array}$ & $\begin{array}{l}\text { Проект «Расширение использования } \\
\text { высокотехнологичной продукции, ус- } \\
\text { луг, в том числе импортозамещающей, } \\
\text { программного обеспечения наукоем- } \\
\text { ких организаций и высших учебных } \\
\text { организаций Пермского края в интере- } \\
\text { сах ОАО „Газпром“» }\end{array}$ \\
\hline $\begin{array}{l}\text { Стратегия развития } \\
\text { энергомашинострое- } \\
\text { ния РФ на 2010- } \\
2020 \text { гг. и на перспек- } \\
\text { тиву до } 2030 \text { г. }\end{array}$ & $\begin{array}{l}\text { «Экономическое раз- } \\
\text { витие и инновацион- } \\
\text { ная экономика» [32], } \\
\text { «Развитие науки и } \\
\text { технологий на 2013- } \\
2020 \text { годы» [33] }\end{array}$ & $\begin{array}{l}\text { Строительство энергоблока } \\
\text { ПГУ-800 МВт Пермской ГРЭС; } \\
\text { Строительство объектов генерации, } \\
\text { функционирующих на основании ис- } \\
\text { пользования энергии ветра; Инноваци- } \\
\text { онный территориальный кластер воло- } \\
\text { конно-оптических технологий } \\
\text { «Фотоника» }\end{array}$ \\
\hline
\end{tabular}


Окончание табл. 4

\begin{tabular}{|c|c|c|}
\hline Стратегии развития & Нормативно-правовая база & $\begin{array}{c}\text { Проекты, реализуемые } \\
\text { в Пермском крае }\end{array}$ \\
\hline $\begin{array}{l}\text { Стратегия развития } \\
\text { тяжелого машино- } \\
\text { строения на период } \\
\text { до } 2020 \text { г. }\end{array}$ & $\begin{array}{l}\text { «Развитие промышленности } \\
\text { и повышение ее конкуренто- } \\
\text { способности» [31], «Разви- } \\
\text { тие оборонно-промышлен- } \\
\text { ного комплекса» [34] }\end{array}$ & $\begin{array}{l}\text { Проект «Федеральные инвести- } \\
\text { ции - пермским предприятиям» }\end{array}$ \\
\hline $\begin{array}{l}\text { Государственная про- } \\
\text { грамма РФ «Развитие } \\
\text { авиационной про- } \\
\text { мышленности» на } \\
\text { 2013-2025 гг. }\end{array}$ & $\begin{array}{l}\text { «Развитие промышленности } \\
\text { и повышение ее конкуренто- } \\
\text { способности» [31], «Разви- } \\
\text { тие авиационной промыш- } \\
\text { ленности на 2013-2025 го- } \\
\text { ды» [35]; «Развитие } \\
\text { оборонно-промышленного } \\
\text { комплекса» [34] }\end{array}$ & $\begin{array}{l}\text { Создание производственного } \\
\text { комплекса серийного изготов- } \\
\text { ления РД-191 и других перспек- } \\
\text { тивных жидкостных ракетных } \\
\text { двигателей (ПАО Протон-ПМ); } \\
\text { Инновационный территориаль- } \\
\text { ный кластер «Технополис Но- } \\
\text { вый Звездный» }\end{array}$ \\
\hline $\begin{array}{l}\text { Стратегия развития } \\
\text { судостроительной про- } \\
\text { мышленности на пери- } \\
\text { од до } 2020 \text { г. и на даль- } \\
\text { нейшую перспективу } \\
\end{array}$ & $\begin{array}{l}\text { «Развитие промышленности } \\
\text { и повышение ее конкуренто- } \\
\text { способности» [31] }\end{array}$ & $\begin{array}{l}\text { Проект «Федеральные инвести- } \\
\text { ции - пермским предприятиям» }\end{array}$ \\
\hline $\begin{array}{l}\text { Стратегия развития } \\
\text { сельскохозяйственно- } \\
\text { го машиностроения } \\
\text { России на период до } \\
2030 \text { г. }\end{array}$ & $\begin{array}{l}\text { «Экономическое развитие } \\
\text { и инновационная экономи- } \\
\text { ка» [32], «Развитие науки } \\
\text { и технологий на 2013- } \\
2020 \text { годы» [33] }\end{array}$ & $\begin{array}{l}\text { Приоритетные инвестиционные } \\
\text { проекты в области освоения лесов: } \\
\text { 1. Проект ОАО «Пиломатериа- } \\
\text { лы «Красный Октябрь». } \\
\text { 2. Проект ООО «Пермский фа- } \\
\text { нерный комбинат». } \\
\text { 3. Проект ОАО «Соликамск- } \\
\text { бумпром». } \\
\text { 4. Проект ООО «Уралбумага». } \\
\text { 5. Проект ОАО «Пермский до- } \\
\text { мостроительный комбинат». } \\
\text { 6. Проект ООО «Капитал-3». } \\
\text { 7. Проект ООО «Горнозаводск- } \\
\text { ЛесПром», Проект по индуст- } \\
\text { рии детских товаров }\end{array}$ \\
\hline
\end{tabular}

Таким образом, реализация механизмов адаптации стратегий предприятий машиностроительного комплекса к приоритетным направлениям развития страны и основным принципам стратегирования на уровне региона, может быть сформирована на основе ряда индикаторов:

- повышение конкурентоспособности на новых рынках (развитие «опережающих» направлений деятельности);

- динамика развития отраслевых рынков - потребителей продукции машиностроительной продукции;

- динамика развития инновационных кластерных образований, обеспечивающих цели цифровизации экономики; 
- развитие инновационной деятельности в технологиях двойного назначения;

- повышение способности отвечать требованиям потребителей на новых рынках и в новых структурах взаимодействия.

\section{Список литературы}

1. Пыткин А.Н., Сухих В.А., Урасова А.А. Особенности развития промышленного комплекса в Пермском крае в условиях членства России в ВТО // Вестник Пермского университета. - 2015. - № 2 (25). - С. 71-80.

2. Перес К. Технологические революции и финансовый капитал. Динамика пузырей и периодов процветания. - М.: Дело; РАНХиГС, 2011. - 232 с.

3. Романова О.А., Акбердина В.В., Бухвалов Н.Ю. Общие ценности в формировании современной технико-экономической парадигмы // Экономические и социальные перемены: факторы, тенденции, прогноз. - 2016. № 3 (45). - С. 173-190.

4. Бархатов В.И., Бенц Д.С. Промышленные рынки Уральского региона: экономический рост в условиях «новой нормальности» // Управленец. 2019. - Т. 10, № 3. - С. 83-93.

5. Дубровина Н.А. Механизм формирования стратегии научно-технологического развития машиностроительного комплекса // Вестник Самарского государственного университета. - 2014. - № 6 (117). - С. 209-216.

6. АО «Александровский машиностроительный завод»: офиц. сайт. URL: http://www.amz.perm.ru/contacts/ (дата обращения: 10.06.2018).

7. Пермский завод «Машиностроитель»: офиц. сайт. - URL: http://pzmash.ru/ (дата обращения: 10.06.2018).

8. АО «Редуктор-ПМ»: офиц. сайт. - URL: http://www.russianhelicopters. aero/ru/reductor-pm/ (дата обращения: 10.06.2018).

9. АО «ОДК-СТАР»: офиц. сайт. - URL: http://www.ao-star.ru/ru (дата обращения: 10.06.2018).

10. НПО «Искра»: офиц. сайт. - URL: http://www.npoiskra.ru/ (дата обращения: 10.06.2018).

11. ООО «Джон Крейн - Искра»: офиц. сайт. - URL: http://johncraneiskra.ru/ (дата обращения: 10.06.2018).

12. АО «ОДК-Пермские моторы»: офиц. сайт. - URL: http://www.pmz.ru/ (дата обращения: 10.06.2018).

13. ПАО «Синергия»: офиц. сайт. - URL: http://www.sinergia.ru/ (дата обращения: 10.06.2018).

14. АО «НОВОМЕТ-Пермь»: офиц. сайт. - URL: http://www. Novometgroup.com / (дата обращения: 10.06.2018). 
15. ООО «Очерский машиностроительный завод»: офиц. сайт. - URL: http:// www.ocher.ru/ (дата обращения: 10.06.2018).

16. ЗАО «Пермская компания нефтяного машиностроения»: офиц. сайт. - URL: http://www.pknm.ru (дата обращения: 10.06.2018).

17. ООО «Краснокамский завод тяжелого машиностроения: офиц. сайт. - URL: http://www.krmz.info/ (дата обращения: 10.06.2018).

18. ПАО «Мотовилихинские заводы»: офиц. сайт. - URL: http://www.mzperm.ru/ (дата обращения: 10.06.2018).

19. АО «ОДК-Авиадвигатель»: офиц. сайт. - URL: http://www.avid.ru/ (дата обращения: 10.06.2018).

20. ООО «Верхнекамский судостроительный комплекс»: офиц. сайт. URL: http://wsk.perm.ru/ (дата обращения: 10.06.2018).

21. ООО «Навигатор - Новое машиностроение»: офиц. сайт. - URL: http://www.nm-agro.ru/ (дата обращения: 10.06.2018).

22. АО «Пермглавснаб»: офиц. сайт. - URL: http://www.permglavsnab.ru (дата обращения: 10.06.2018).

23. «Galileosky»: офиц. сайт. - URL: https://7gis.ru/ (дата обращения: 10.06.2018).

24. ПАО «Пермская научно-производственная приборостроительная компания»»): офиц. сайт. - URL: http://ppk.perm.ru/ppk60/ (дата обращения: 10.06.2018).

25. Бурцева Н.Л. Ракетный двигатель РД-171 MB - мощь, побеждающая гравитацию // Воздушно-космическая сфера. - 2019. - № 2 (99). - С. 20-25.

26. Эксперты СоюзМаш и Роскосмоса обсудили стратегию цифровизации ракетно-космической отрасли [Электронный ресурc]. - URL: http://www.engine.space (дата обращения: 12.12.2019).

27. Офиц. сайт губернатора и правительства Пермского края. - URL: http://www.permkrai.ru (дата обращения: 15.07.2018).

28. Пермский край в цифрах. 2019: крат. стат. сб. / Террит. орган Федер. службы гос. статистики по Перм. краю. - Пермь, 2019 - 200 с.

29. Министерство промышленного развития Пермского края: офиц. сайт. URL: http://www.minpromtorg.permkrai.ru (дата обращения: 12.12.2019).

30. Стратегия инновационного развития РФ до 2020 г.: Постановление Правительства РФ от 8 дек. 2011 г. № 2227-р. - Доступ из справ.-правовой системы «КонсультантПлюс: Версия Проф» (дата обращения: 10.10.2019).

31. Развитие промышленности и повышение ее конкурентоспособности: Постановление Правительства РФ от 15 апр.2014 г. № 328. - Доступ из справ.-правовой системы «КонсультантПлюс: Версия Проф» (дата обращения: 10.10.2019).

32. Экономическое развитие и инновационная экономика: Постановление Правительства РФ от 15 апр. 2014 № 316. - Доступ из справ.-правовой системы «КонсультантПлюс: Версия Проф» (дата обращения: 10.10.2019). 
33. Развитие науки и технологий на 2013-2020 годы: Постановление Правительства РФ от 15 апр. 2014 № 301. - Доступ из справ.-правовой системы «КонсультантПлюс: Версия Проф» (дата обращения: 10.10.2019).

34. Развитие оборонно-промышленного комплекса: Постановление Правительства РФ от 16 мая 2016 № 425-8. - Доступ из справ.-правовой системы «КонсультантПлюс: Версия Проф» (дата обращения: 10.10.2019).

35. Развитие авиационной промышленности на 2013-2025 годы: Постановление Правительства РФ от 15 апр. 2014 № 303 - Доступ из справ.правовой системы «КонсультантПлюс: Версия Проф» (дата обращения: 10.10.2019).

\section{References}

1. Pytkin A.N., Sukhikh V.A., Urasova A.A. Osobennosti razvitiia promyshlennogo kompleksa v Permskom krae v usloviiakh chlenstva Rossii v VTO [Developing industrial complex in Perm Krai under the conditions of Russia's membership in the WTO]. Vestnik Permskogo universiteta, 2015, no. 2(25), pp. 71-80.

2. Perez C. Technological revolutions and financial capital: The dynamics of bubbles and golden ages (Russ. ed.: Peres K. Tekhnologicheskie revoliutsii i finansovyi kapital. Dinamika puzyrei i periodov protsvetaniia. Moscow, Delo, RANKhiGS, 2011, 232 p.).

3. Romanova O.A., Akberdina V.V., Bukhvalov N.Iu. Obshchie tsennosti v formirovanii sovremennoi tekhniko-ekonomicheskoi paradigmy [Shared values in the formation of a modern techno-economic paradigm]. Ekonomicheskie $i$ sotsial'nye peremeny: faktory, tendentsii, prognoz, 2016, no. 3(45), pp. 173-190.

4. Barkhatov V.I., Bents D.S. Promyshlennye rynki Ural'skogo regiona: ekonomicheskii rost v usloviiakh "novoi normal'nosti" [Industrial markets of the Ural region: Economic growth under "new normal"]. Upravlenets, 2019, vol. 10, no. 3, pp. 83-93.

5. Dubrovina N.A. Mekhanizm formirovaniia strategii nauchnotekhnologicheskogo razvitiia mashinostroitel'nogo kompleksa [Mechanism of formation of the strategy of science and technology development of machine building complex]. Vestnik Samarskogo gosudarstvennogo universiteta, 2014, no. 6(117), pp. 209-216.

6. AO "Aleksandrovskii mashinostroitel'nyi zavod" [AO Alexandrovsky machine-building plant]. Available at: http://www.amz.perm.ru/contacts/ (accessed 10 June 2018).

7. Permskii zavod "Mashinostroitel"' [Mashinostroitel Perm plant]. Available at: http://pzmash.ru/ (accessed 10 June 2018).

8. AO "Reduktor-PM" [AO Reduktor-PM] Available at: http://www.russianhelicopters. aero/ru/reductor-pm/ (accessed 10 June 2018). 
9. AO “ODK-STAR" [AO ODK-STAR]. Available at:: http://www.aostar.ru/ru (дата обращения: 10.06.2018).

10. NPO "Iskra" [NPO Iskra]. Available at: http://www.npoiskra.ru/ (дата обращения: 10.06.2018).

11. OOO "Dzhon Krein-Iskra" [OOO John Crane-Iskra]. Available at: http://johncraneiskra.ru/ (accessed 10 June 2018).

12. AO "ODK-Permskie motory" [JSC UEC-Perm Motors]. Available at: http://www.pmz.ru/ (accessed 10 June 2018).

13. PAO "Sinergiia" [PAO Synergy]. Available at: http://www.sinergia.ru/ (accessed 10 June 2018).

14. AO "NOVOMET-Perm"” [AO NOVOMET-Perm]. Available at: http://www. Novometgroup.com / (accessed 10 June 2018).

15. OOO "Ocherskii mashinostroitel'nyi zavod" [OOO Ochersky machinebuilding plant]. Available at: http:// www.ocher.ru/ (accessed 10 June 2018).

16. ZAO "Permskaia kompaniia neftianogo mashinostroeniia" [ZAO Perm Oil Machine Engineering Company]. Available at: http://www.pknm.ru (accessed 10 June 2018).

17. OOO "Krasnokamskii zavod tiazhelogo mashinostroeniia" [OOO Krasnokamsk machinery and repair plant]. Available at: http://www.krmz.info/ (accessed 10 June 2018).

18. PAO "Motovilikhinskie zavody" [PJSC Motovilikhinskiye plants]. Available at: http://www.mzperm.ru/ (accessed 10 June 2018

19. AO "ODK-Aviadvigatel"' [JSC UEC-Perm Engines]. Available at: http://www.avid.ru/ (accessed 10 June 2018).

20. OOO "Verkhnekamskii sudostroitel'nyi kompleks" [OOO Verkhnekamsk shipbuilding complex]. Available at: http://wsk.perm.ru/ (accessed 10 June 2018).

21. OOO "Navigator - Novoe mashinostroenie" [Navigator CS LLC]. Available at: http://www.nm-agro.ru/ (accessed 10 June 2018).

22. AO "Permglavsnab" [AO Permglavsnab]. Available at: http://www.permglavsnab.ru (accessed 10 June 2018).

23. Galileosky. Available at: https://7gis.ru/ (accessed 10 June 2018).

24. PAO "Permskaia nauchno-proizvodstvennaia priborostroitel'naia kompaniia" [JSC Perm Research and Production Instrument Company]. Available at: http://ppk.perm.ru/ppk60/ (accessed 10 June 2018).

25. Burtseva N.L. Raketnyi dvigatel' RD-171 MV-moshch', pobezhdaiushchaia gravitatsiiu [RD-171MV rocket engine-power that conquers gravity]. Vozdushno-kosmicheskaia sfera, 2019, no. 2(99), pp. 20-25.

26. Eksperty SoiuzMash i Roskosmosa obsudili strategiiu tsifrovizatsii raketno-kosmicheskoi otrasli [Experts of SoyuzMash and Roscosmos have discussed digitalization strategy for the rocket and space industry]. Available at: http://www.engine.space (accessed 12 December 2019). 
27. Official site of the Governor and the Government of the Perm Krai. Available at: http://www.permkrai.ru (accessed 15 July 2018).

28. Permskii krai v tsifrakh. 2019 [The Perm Krai in numbers. 2019]. Federal State Statistic Service. Perm, 2019, 200 p.

29. Ministry of Industrial Development of the Perm Krai. Available at: http://www.minpromtorg.permkrai.ru (accessed 12 December 2019).

30. Strategiia innovatsionnogo razvitiia RF do 2020 g. [Innovative development strategy of the Russian Federation up to 2020]. Government Decree of the RF of Dec. 08, 2011 no.2227-r. Konsul'tant Iurist: Versiia Prof (accessed 10 October 2019).

31. Razvitie promyshlennosti i povyshenie ee konkurentosposobnosti [Development of the industry and improving its competetiveness]. Government Decree of RF of Apr. 15, 2014 no. 328. Available at: http://www.consultant.ru/ (accessed 10 October 2019).

32. Ekonomicheskoe razvitie i innovatsionnaia ekonomika [Economic development and innovative economy]. Government Decree of the RF of Apr. 15, 2014 no. 316. Available at: http://www.consultant.ru/ (accessed 10 October 2019).

33. Razvitie nauki i tekhnologii na 2013-2020 gody [Development of science and technology for the period 2013-2020]. Government Decree of the RF of Apr. 15, 2014 no. 301. Available at: http://www.consultant.ru/ (accessed 10 October 2019).

34. Razvitie oboronno-promyshlennogo kompleksa [Development of the military-industrial complex]. Government Decree of the RF of May 16, 2016, no. 425-8. Available at: http://www.consultant.ru/ (accessed 10 October 2019).

35. Razvitie aviatsionnoi promyshlennosti na 2013-2025 gody [Development of the aviation industry for the period 2013-2025]. Government Decree of RF of Apr. 15, 2014 no. 303 Available at: http://www.consultant.ru/ (accessed 10 October 2019).

Оригинальность $75 \%$

Получено 17.12.2019 Принято 17.01.2020 Опубликовано 27.03.2020 


\author{
E.S. Lobova, L.N. Mamaeva, T.G. Mentemirova, K.A. Shishkina
}

\title{
OPPORTUNITIES OF STRATEGIC DEVELOPMENT FOR THE MACHINE-BUILDING ENTERPRISES IN THE LIGHT OF PRIORITY AVENUES OF RUSSIA' INDUSTRIAL DEVELOPMENT
}

\begin{abstract}
The current state of the markets for industrial products is largely influenced by the processes associated with a widespread digitalization and development of the concept of Industry 4.0. The institutionalization of priority areas and strategies for sectoral development at the regional level should serve as the basis for the formation of innovative principles of interaction and the development of new approaches to determining competitiveness. The constituent elements of the Perm Krai's strategic development vector focused on the formation of "growth drivers" are both the structural features of the industry and innovative solutions regarding growth points for high-tech markets. The purpose of the study is to identify the main parameters of the strategic positioning of the machine-building enterprises that meet the conditions for strategizing of innovation-oriented participants at all levels of the socio-economic system. To achieve the goal, the authors explore the main promising avenues of the Perm Krai's industrial development and their relationship with the concept of Industry 4.0. The principles of forming parametric indicators of the "growth drivers" feasibility in relation to the machine-building complex are substantiated. The paper determines interconnections of the criteria of strategic management at the leading enterprises of the machine-building complex with the target indicators of sectoral strategies of macro- and mesoscale levels. The role of institutionalization of strategic parameters in the formation of the technological potential of machine-building enterprises is emphasized. The main results include the mechanism for substantiating the parameters of the feasibility study of the activities of the Perm Krai's leading enterprises, as well as the parameters on the basis of which one can judge the achievement of the interests of the participants in the strategic planning of growth points.
\end{abstract}

Keywords: industry, machine-building enterprises, strategic planning, Industry 4.0.

Elena S. Lobova - Candidate of Economic Sciences, Associate Professor, Department of Economics and Industrial Production Management, Perm National Research Polytechnic University, e-mail: bykova555@rambler.ru.

Lyudmila N. Mamaeva - Candidate of Economic Sciences, Associate Professor, Department of Economic Security, Saratov Socio-Economic Institute (branch), Plekhanov Russian University of Economics, e-mail: L.Mamaeva2014@yandex.ru.

Tatyana G. Mentemirova - Master's Student, Department of Economics and Industrial Production Management, Perm National Research Polytechnic University, e-mail: tatyanamentemirova@yandex.ru.

Kseniya A. Shishkina - Master's Students, Department of Economics and Industrial Production Management, Perm National Research Polytechnic University, e-mail: shishckina.xenia2014@yandex.ru.

Received 17.12.2019 Accepted 17.01.2020 Published 27.03.2020 